\title{
A Measure of Dynamic Market Performance
}

\author{
René Y. Darmon ${ }^{1 *}$, Louis Duclos-Gosselin ${ }^{2}$, Benny Rigaux-Bricmont ${ }^{3}$ \\ ${ }^{1}$ Marketing Department, ESSEC Business School, Cergy-Pontoise, France; ${ }^{2}$ Analyse des Modes de Défaillance, de Leurs Effets et de Leurs \\ Criticités, Quebec City, Canada; ${ }^{3}$ Marketing Department, Faculty of Administration Sciences, Laval University, Quebec City, Canada. \\ Email: darmon@essec.fr, louis.gosselin@hotmail.com, benny.rigaux-bricmont@mrk.ulaval.ca
}

Received November $9^{\text {th }}, 2012$; revised December $17^{\text {th }}, 2012$; accepted January $18^{\text {th }}, 2013$

Copyright (C) 2013 René Y. Darmon et al. This is an open access article distributed under the Creative Commons Attribution License, which permits unrestricted use, distribution, and reproduction in any medium, provided the original work is properly cited.

\begin{abstract}
This paper proposes an easy-to-implement dynamic measure of market performance over time for various selling units (e.g., sales territories, sales regional offices, or the whole sales organization). It may be used as a diagnosis tool by comparing the market performances of various units, taking into account the conditions prevailing in the different markets (such as competition relative effectiveness, sales penetration, or local market fluctuations). Combining sales volume, market share, and profit variations data into an Index of Sales Unit Market Performance (ISUMP), provides managerial guidance for selling units' evaluation or resource allocations among units. This index may account for a firm's selected market strategy (market penetration, market skimming, etc.). Implementation in a large North American insurance company is reported.
\end{abstract}

Keywords: Selling Units; Market Performance; Sales Performance; Market Shares; Selling Unit Control

\section{Introduction}

Many managerial marketing decisions (e.g., budget and resource allocations) and sales force decisions aim at maintaining or improving the performance of various selling units over time [1-3]. A selling unit is an entity responsible for achieving some output market performance. It may be, for instance, a sales territory (either assigned to a sales team or to an individual salesperson), a regional or district sales office, or the whole sales organization. Every selling unit is characterized by its market output performance (such as sales, profits, or market share) that results from the accomplishment of the selling tasks, in a specific environment, over some long- and/or short-term period of time.

In order to effectively manage and control selling units, managers must rely on valid and accurate measures of market performance [4]. Inaccurate assessments may lead to poor managerial decisions, feelings of inequity, morale problems, lack of organizational commitment, and dysfunctional turnover [5-8]. For that purpose, managers generally collect and analyze large amounts of data, often frequently supplied by CRM applications. However, it is often difficult to devise adequate measures of market performance [9]: this concept covers, among

${ }^{*}$ Corresponding author. others, short- and long-term variations in sales, profits, customer satisfaction, loyalty building, and customer relationship development; it is multidimensional $[9,10]$ and consequently, no single measure can account for its various dimensions. This is exemplified by the large number of definitions and measures used for that purpose $[2,3]$, that range from managerial subjective judgments and self-assessments [6] to simplistic measures, like sales volumes [10]. A meaningful measure of market performance should capture the extent to which a selling unit is able to take advantage of market opportunities (or lack thereof) in order to achieve a firm's desired market position and implement its selling strategy. Managers often lack such simple measures.

The aim of this paper is to devise a measure of a selling unit's market performance over time that could supplement the management's control tool kit. When considered jointly with extra-role performance measures [11], this market performance measure allows managers to make better diagnoses, and consequently, to provide better managerial guidance for selling units' evaluation, organization, compensation, and/or resource allocations [12].

After discussing the concept of selling units' market performance measurement, the proposed procedure is described. An application illustrates the concept. Fi- 
nally, the advantages and limits of this procedure are discussed.

\section{Selling Units’ Market Performance Measures}

Assessing market performance is fraught with difficulty, and sales force researchers and sales managers have typically used different approaches to that purpose [1321].

\subsection{Sales Force Researchers’ Approaches}

Over the last decades, a major stream of sales force research has attempted to gain better understanding of salespeople's performance and to find appropriate ways to enhance selling effectiveness [22]. The seminal work by [23] that proposed a model of the major determinants and consequences of sales force performance has been followed by many studies sharing similar concerns [2429]. These studies have investigated the antecedent and/ or consequences of salespeople's sales performance and/ or effectiveness [30-32].

In most cases, researchers have measured selling units' performance either using objective sales data [11] or evaluative scales [6]. Measurement instruments have been completed by managers, by salespersons themselves (selfreports) [12,33-35], or both [36-38]. It seems that, in practice, research suggests that subjective and objective measures lead to different results [39-44]. Unfortunately, because they are highly subjective and may well yield biased judgments $[45,46]$, their validity is often questionable $[44,47]$, and they can have only limited practical value. Consequently, such self-report evaluative scales are seldom used alone in the practice of sales management.

\subsection{Sales Managers’ Approaches}

In order to assess selling unit market performance, managers have typically used quantitative and/or qualitative measures [48]. Here again, the former measures (such as sales volume) tend to be objective and easy to assess. Unfortunately, they seldom capture the qualitative aspects of the selling job, especially the extra-role performance aspects [11]. In addition, they are inadequate for assessing the unit's performance over time, taking into account the effects of environmental variables on market size. A selling unit's sales performance results from many other factors than the marketing resources deployed in this unit [49], for instance, each unit's environmental conditions (competitive strength, economic conditions, etc.).

Alternatively, in order to explain management controls of the sales force, some authors have made a distinction between behavior- and outcome-based sales force con- trols [50-52]. Although controlling salespeople's behaviors is an important and necessary aspect of sales management [53,54], it would be worthless if the proper behaviors did not eventually translate into sales, profits, market shares, strengthened customer relationships, or clients' satisfaction. In practical situations, managers do evaluate selling unit market performance from at least some objective quantitative measures of sales performance [55], and outcome performance is always part of a sales force control process [56-58]. Although outcome performance measures are always used by management, few, if any, can provide a fair assessment of a sales unit's market performance.

Territory sales volume, market shares, or profits, which are typically observed by managers, are inadequate market performance measures when considered individually. As stated above, although selling units are instrumental in building sales volume over time, sales are also influenced by a host of factors which are beyond the unit's control. In most cases, managers cannot easily disentangle what parts of such outcomes must be attributed to a selling unit's marketing program (attractiveness of the offers, advertising, company's reputation, etc.), or to environmental factors (competitive strength, economic trends, etc.). As a result, sales volume alone may give a distorted picture of this unit's market performance [35,59]. Although territory market shares bring the additional dimensions of industry sales, competition's performance, and the firm's market penetration, they suffer from the same problems as sales volume. In addition, all outcome measures of performance tend to over-emphasize short-over long-term performances. Finally, selling unit profit measures are useful to watch, in as much as the units are given responsibility to negotiate prices and/or are left to allocate their efforts and resources among several product lines with different profit margins [60]. Being linked to sales, profit measures have the same drawbacks as sales, as market performance measures.

Sales variations over some benchmark period (after removing seasonal effects) are frequently used and provide better measures because they indicate a unit's success (or failure) in sustaining a given level of sales over time. Taken alone, however, sales variations can be misleading because they may also be caused by many factors beyond a selling unit's control (for instance, a shift in territory environmental conditions, windfall sales in any of the two periods, or simply random factors affecting sales in one or both periods of time).

Customer satisfaction could be a more appealing measure, because it involves an important long-term firm's objective. Unfortunately, customer satisfaction variations are not always easy to measure. In addition, research 
suggests that salespersons' confusion can result from control systems that combine both customer satisfaction and short-term performance measures such as sales [61]. Not surprisingly, a survey has shown that only a relatively small proportion of firms (about 25 percent) use customer satisfaction as a basis for selling unit performance evaluation and rewards [62].

Market share variations in a selling unit's territory provide a clear indication of a firm's standing in its market. It measures a company's market penetration, and, to some extent, the selling unit is responsible for it. Market share brings the additional dimension of industry sales, and consequently, of competitive performance. Competitive sales performance constitutes a natural benchmark for evaluating selling units' market performances. In other words, it is essential to account for the evolution of the competition's sales levels for evaluating selling unit market performance.

When territory sales, industry sales, market shares, and profit variations are considered jointly, they provide a more complete assessment of a selling unit market performance. Various market conditions require different efforts and abilities [36]. Increasing or even maintaining sales volume and/or profits in a declining market are indicative of higher market performance than the same achievement in a fast expanding market. A few methods, such as data envelopment analysis (DEA) [14,63] have been proposed and sometimes used in practice for addressing the problem of evaluating selling units' market performance with multiple criteria [64]. This technique relies on linear aggregations of various inputs and outputs and compares every selling unit to the "best" performing one. It has, however, a number of limitations, the most serious ones being its complexity and difficulty to make it understood by practitioners, its reliance on many subjectively selected criteria, and its sensitivity to measurement errors [14].

Another important dimension of selling unit market performance is the time frame over which it is measured. While building long-term relationships with customers has become a prevalent strategy, short-term sales have often become inadequate measures of market performance. The current emphasis on sales activity based at the expense of outcome-based controls is a logical consequence of this evolution. Consequently, there is a need for devising selling unit's market performance measures that 1) are meaningful to managers, 2) are based on easily observable and quantifiable data, 3) are valid and reflect the ability of selling units to progress, taking into account its market evolution, and 4) can accommodate short- as well as long-run market performance assessments.

Like DEA, the selling unit market performance measure used in this study is also a multi-criterion procedure.
It presents, however, several advantages over DEA: 1) it measures "true" market performance, discarding environmental factors that influence the sales results of every selling unit; 2) unlike DEA which is an extreme point method, it is not sensitive to some unusually high or low unit performances, and consequently to outlying observations; 3 ) it requires much less computations (against one linear program per selling unit in DEA); and 4) it is more easily understood and applicable by managers.

\section{Method}

\subsection{Principle}

Managers assess a selling unit's market performance at time $T_{1}$ by comparing the performance this unit has achieved over some period of time $t$ (typically a few weeks or months, ending at time $T_{1}$ ) to some selected benchmark. Depending on the situation and management's goals, the selected benchmark can be 1) the outcomes achieved during a comparable reference period of length $\mathrm{t}$ (such as the preceding period $\mathrm{T}_{0}$ or some other selected period, or an average of several selected benchmark periods), or 2) some target outcome levels to be achieved during the considered period of time (for instance, some sales objectives or quotas). The analysis can be carried with one or several types of appropriate benchmark.

The choice of a benchmark is crucial and requires careful managerial consideration. Selecting a preceding similar period is appropriate whenever, during this period of time, external factors have not differentially and significantly affected the various selling units.

At some time $T_{1}$, four main factors reflect different aspects of a selling unit's current market performance variation over the benchmark: 1) the total industry sales (IS) variation in this unit: $i s_{1}=\left(I S_{1}-I S_{0}\right) / I S_{0}$; although a selling unit cannot be held responsible for industry sales variations, one should recognize that it is more difficult to improve a firm's market position in a declining than in an expanding market; 2) the unit's sales volume (S) variation $S_{1}=\left(S_{1}-S_{0}\right) / S_{0}$ over the benchmark situation; and 3 ) the corresponding selling unit's market share (MS) variation

$$
\begin{aligned}
m s_{1} & =\left(M S_{1}-M S_{0}\right) / M S_{0} \\
& =\left(S_{1} / I S_{1}-S_{0} / I S_{0}\right) / S_{0} / I S_{0},
\end{aligned}
$$

because performance should account for a selling unit's ability to improve or maintain the firm's market position in its territory; and 4) the corresponding gross profit variations $\pi_{1}=\left(\Pi_{1}-\Pi_{0}\right) / \Pi_{0}$. Being measures of variation (in decimal form), $i s_{1}, s_{1}, m s_{1}$, and $\pi_{1}$ can either be positive or negative (or null) and will typically vary 
between -1 and $+\infty{ }^{1}$.

In order to provide a simpler explanation of the underlying concepts and rationale of the proposed method, a simpler case that does not consider profit variations is discussed first. Then, in a following section, the method is generalized to the case including profit variations.

\subsection{Selling Units' Market Performance (Excluding Gross Profits)}

Table 1 provides an eight-cell cross-tabulation of selling units' market performance situations according to the variation directions of the territory's industry sales $\left(i s_{1}>\right.$ 0 or $<0)$, sales volumes $\left(s_{1}>0\right.$ or $\left.<0\right)$, and market share $\left(m s_{1}>0\right.$ or $\left.<0\right)$. (From here on, for simplification purpose, the subscript 1 will be omitted, unless necessary.)

These three dimensions are somewhat interrelated. Increased sales in a decreasing industry sales territory imply an increased market share (Case 1). Decreased sales in an increasing industry sales market imply a decreased market share (Case 6). No inference about market share variations can be made, however, on the basis of sales and industry sales variations alone when both sales and market industry sales increase (decrease). In such cases, market share increases or decreases, depending on the relative sizes of the sales and industry sales increase (decrease) rates. Therefore, one should explicitly take market share variations into consideration. The six possible cases defined in Table 1 provide clear indications about how a selling unit market position has evolved in its territory over time, taking into account factors over which this unit has no control (such as market size variation, competitive strength, or other factors).

The six situations described above are represented graphically in Figure 1 (Zone 1 to 6). This diagram relates a selling unit's territory sales $(s)$ and market share $(m s)$ variations over the benchmark. For instance, a selling unit A may have experienced a sales increase $\left(s_{a}\right)$ and a market share increase $\left(m s_{a}\right)$ and consequently be positioned at point A in Figure 1. The slope of the vector NA reflects the corresponding industry sales variation $\left(i s_{a}\right)$ during that period of time. Note that every selling unit's vector must start at point $\mathrm{N}(-1,-1)$ (a $100 \%$ sales de-

${ }^{1}$ All the selling units are assumed to make at least some profit in $T_{0}$ and $\mathrm{T}_{1}$. In some relatively rare instances, however, it may be possible to observe $\pi_{1}<-1$ whenever a loss rather than a profit occurs in either $T_{0}$ or $T_{1}$. In such cases, a profit (or loss) percentage variation is meaningless. Whenever this situation arises, the problem can be handled in different ways: 1) excluding such selling units from this analysis and dealing with them separately; 2) If the loss is small and affects a relatively small number of selling units, the profit variation can be approximated by the -1 value (this would slightly overestimate these selling units' market performance); 3) the reference period could be changed (or replaced by objectives) in order to suppress the problem; and 4 ) the same profit amount could be added to the profit results in $T_{0}$ and $T_{1}$ for all the selling units, in such a way as to suppress the loss for the largest losing selling unit. crease always implies a $100 \%$ market share decrease). Because industry sales variations are generally beyond their control, selling units cannot choose the slope of the vector along which they can move. However, how far they move on their respective vectors in the direction of the arrow does reflect the quantity and quality of the work accomplished by the firm in this territory. The length of the vector NA reflects Selling Unit A's market performance. In other words, the unit's market performance (the length of Vector NA) has been disentangled from uncontrollable market size variations (the slope of Vector NA).

Although theoretically, $\mathrm{s}$, is, and ms can possibly vary between -1 and infinity, in most usual cases, their values are likely to be relatively close to zero $(\mathrm{NO}=$ status quo, i.e., no change over the benchmark: $s=i s=m s=0$ ). The six zones shown in Figure 1 correspond to the six cases in Table 1. Because the length of the vector is characteristic of a given selling unit market performance, isomarket performance curves are quarter of circles centered on $\mathrm{N}$. A larger radius of the circle reflects a higher market performance level.

In order to compare the market performance of various selling units, one can compare the percentages by which each one has moved on its vector compared with the status quo N0. A formal measure called ISUMP (Index of Selling Unit Market Performance) can be used to that effect.

\subsection{Analytical Formulation}

Let successively be sales variations $(s)$, industry sales variations (is) and market share variations $(m s)$ in Selling Unit i's territory (all in decimal form) (subscript $i$ omitted unless necessary):

$$
s=\left(S_{1}-S_{0}\right) / S_{0}, s \geq-1
$$

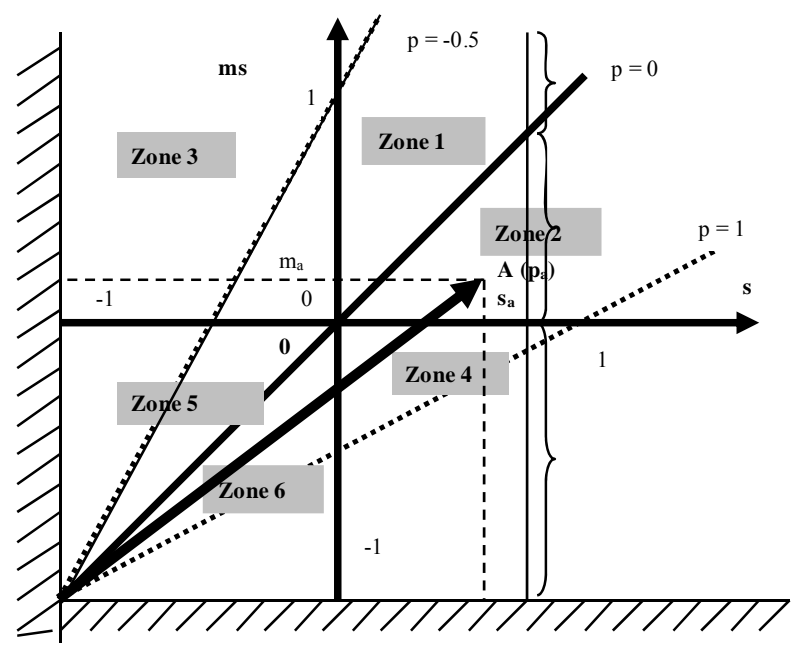

Figure 1. The six performance zones. 
Table 1. Six possible strategic performance situations according to territory sales, market industry sales, and market share variations.

\begin{tabular}{|c|c|c|c|c|}
\hline & \multicolumn{2}{|c|}{ Sales increase $(s>0)$} & \multicolumn{2}{|c|}{ Sales decrease $(s<0)$} \\
\hline & $\begin{array}{l}\text { Market share increase } \\
\qquad(m s>0)\end{array}$ & $\begin{array}{l}\text { Market share decrease } \\
\qquad(m s<0)\end{array}$ & $\begin{array}{l}\text { Market share increase } \\
\qquad(m s>0)\end{array}$ & $\begin{array}{l}\text { Market share decrease } \\
\qquad(m s<0)\end{array}$ \\
\hline $\begin{array}{l}\text { Industry } \\
\text { sales } \\
\text { increase } \\
(\text { is }>0)\end{array}$ & $\begin{array}{l}\text { Case } 2 \\
\text { Sales increase at a higher } \\
\text { rate than market potential. } \\
\text { The salesperson strengthens } \\
\text { the company position in } \\
\text { an expanding market } \\
\text { demand territory. }\end{array}$ & $\begin{array}{c}\text { Case } 4 \\
\text { Sales increase, but at a lower } \\
\text { rate than market industry sales. } \\
\text { The salesperson weakens the } \\
\text { company position in an } \\
\text { expanding market demand } \\
\text { territory. }\end{array}$ & IMPOSSIBLE & $\begin{array}{c}\text { Case } 6 \\
\text { Sales and market share decrease } \\
\text { in an expanding market. The } \\
\text { salesperson cannot take advantage } \\
\text { of the market opportunities in the } \\
\text { territory. }\end{array}$ \\
\hline $\begin{array}{c}\text { Industry } \\
\text { sales } \\
\text { decrease } \\
(\text { is }<0)\end{array}$ & $\begin{array}{l}\text { Case 1 } \\
\text { Sales and market share } \\
\text { increase as the market shrinks. } \\
\text { The salesperson strengthens } \\
\text { the company position in a } \\
\text { declining market demand } \\
\text { territory. }\end{array}$ & IMPOSSIBLE & $\begin{array}{l}\text { Case } 3 \\
\text { Sales decrease but at a lower } \\
\text { rate than the market industry } \\
\text { sales. } \\
\text { The salesperson offers a } \\
\text { strong resistance against the } \\
\text { declining market demand in } \\
\text { the territory. }\end{array}$ & $\begin{array}{l}\text { Case } 5 \\
\text { Sales decrease at a higher rate } \\
\text { than the market industry sales. } \\
\text { The salesperson weakens the } \\
\text { company position in a declining } \\
\text { market demand in the territory. }\end{array}$ \\
\hline
\end{tabular}

$$
\begin{gathered}
i s=\left(I S_{1}-I S_{0}\right) / I S_{0}, i s \geq-1 \\
m s=\left(M S_{1}-M S_{0}\right) / M S_{0}, m s \geq-1,
\end{gathered}
$$

with $M S_{0}=S_{0} / I S_{0}$, and $M S_{1}=S_{1} / I S_{1}$, where:

$S_{1}=$ sales level achieved by Selling unit i in period 1, in dollars;

$S_{0}=$ sales level for this unit in the benchmark situation, in dollars;

$I S_{1}=$ industry sales in period 1 , in dollars;

$I S_{0}=$ industry sales in the benchmark situation, in dollars;

$M S_{1}=$ market share achieved in this unit's territory in period 1, in decimal form;

$M S_{0}=$ market share for this selling unit's territory in the benchmark situation, in decimal form.

Replacing $S_{1}$ and $I S_{1}$ by their values in (1) and (2) in Equation (3) leads to:

$$
m s=[1 /(i s+1)] s-[i s /(i s+1)]
$$

Given specific values of is $(-1 \leq i s<+\infty)$, one can determine the linear relationship linking market share $m s$ to sales volume $s$ variations, as shown in Equation (4). Thus, for $i s=-1, m s \geq+\infty$; for $i s=-1 / 2, m s=2 s+1$; for $i s=$ $0, m s=s$, and for $i s=1, m s=s / 2-1 / 2$. In the same way, because the three concepts are interrelated, each one can be expressed as a function of the other two:

$$
s=m s(i s+1)+i s \text { and } i s=(s-m s) /(m s+1)
$$

As shown in Figure 1, every selling unit can move along a vector characteristic of its territory situation, and market performance is reflected by the position an entity has reached on its vector. By simple application of the
Pythagorean Theorem, the status quo (benchmark situation) iso-performance curve has a radius equal to the square root of 2 , i.e. $(2)^{1 / 2}$.

In order to compare the market performance achieved by various selling units, one must assess by which percentage each unit has moved on its vector from the status $q u o$. For a given unit $i$ which has achieved sales variations of $s_{i 0}$ and market share variation of $m s_{i 0}$ in period 1 , the market performance increase (or decrease) in comparison with the benchmark situation 0 (or Index of Selling Unit Market Performance, ISUMP) is given by:

$$
\operatorname{ISUMP}=100\left\{\left[\left(1+s_{i 0}\right)^{2}+\left(1+m s_{i 0}\right)^{2}\right] / 2\right\}^{1 / 2}
$$

By replacing $s_{i 0}$ and $m s_{i 0}$ by their values in $(1-3)$ and rearranging the terms leads to another expression of the ISUMP:

$$
\begin{aligned}
& \text { ISUMP } \\
& =\left(100 / I S_{1}\right)\left(S_{1} / S_{0}\right)\left[\left(I S_{1}^{2}+I S_{0}^{2}\right) / 2\right]^{1 / 2}
\end{aligned}
$$

ISUMP $=100$ means no market performance improvement, ISUMP > 100, some improvement, and ISUMP < 100 some market performance decrease. In order to assess how a selling unit's market performance compares with the overall higher order entity (e.g., a given sales territory within its corresponding branch office) market performance, this index can be supplemented by an adjusted ISUMP defined $\mathrm{as}^{2}$ :

$$
\text { Adjusted ISUMP }=\frac{100(\text { entity's ISUMP })}{(\text { higher order entity's ISUMP })}
$$

\footnotetext{
${ }^{2}$ Like in DEA, every selling unit market performance could be related to the "best practice".
} 
The analysis can be supplemented by locating the position of every selling unit on the six-zone map (tips of market performance vectors in Figure 2). For instance, in the reported application (see the following section), the market performance vectors of twenty-eight sales territories (ST1 to ST28) constituted of a 713 salesperson sales force have been cast into one single common graph and can be compared directly. For greater visibility, however, only representative cases from each zone are shown in Figure 2.

\subsection{Selling Units' Market Performance (Including Gross Profits)}

The same principles apply when profit margin variations are added to the analysis. In this case, there are twelve situations (and twelve corresponding zones); each case identified in Table 1 being characterized either by a profit margin ( $p m$ ) increase or decrease over the benchmark. Consequently, all previous zones are split according whether they are characterized by a profit margin increase (indexed a) or a profit margin decrease (indexed $b$ ). As shown in Figure 3, the market performance vectors are cast into a three dimensional space characterized

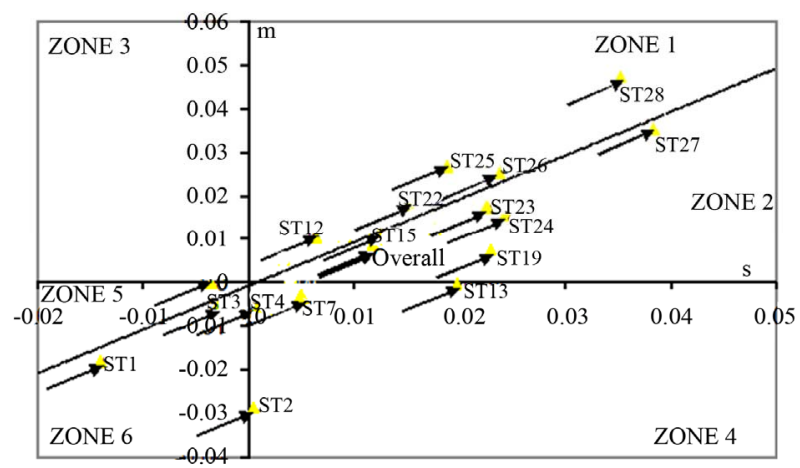

Figure 2. Positions (tips of market performance vectors) of seventeen selected sales manager on the six-zone grid and overall office (darker arrow).

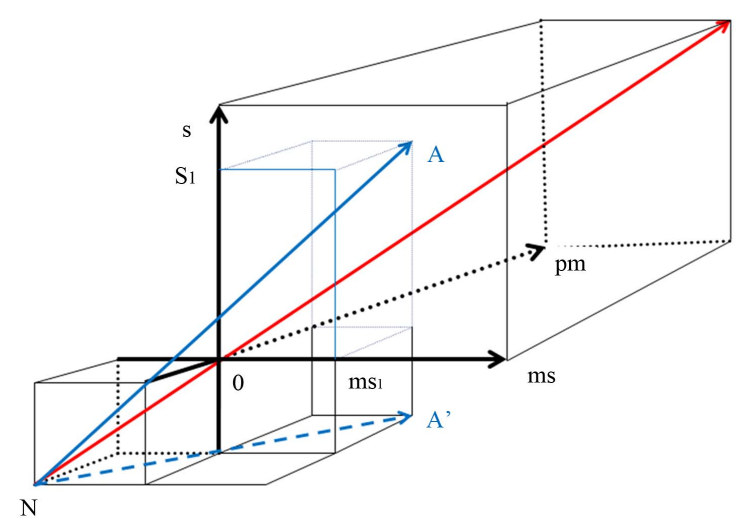

Figure 3. Selling unit's market performance vector in a three dimensional space. by the $s, m s$, and $p m$ variations.

There are two ways through which a selling unit can increase profits: increasing sales and/or the profit margins on the goods or service sold (either through negotiation of higher prices and/or selling more profitable products). The profit situation is therefore characterized by:

$$
\pi_{1}=\left(\Pi_{1}-\Pi_{0}\right) / \Pi_{0} \text {, with } \Pi_{0}=P M_{0} S_{0} \text { and } \Pi_{1}=P M_{1} S_{1}
$$

where $P M_{0}$ and $P M_{1}$ are the profit margin rates respectively in the benchmark situation and achieved in Period 1. Defining the profit margin variation as $p m=\left(P M_{1}-P M_{0}\right) / P M_{0}$ leads to:

$$
\pi=p m+p m s+s \text { or } p m=(\pi-s) /(s+1)
$$

A simple extension of the previous analysis leads to an estimate of the Index of Selling Unit Market Performance (ISUMP):

$$
\operatorname{ISUMP}=100\left\{\left[\left(1+m s_{i 0}\right)^{2}+\left(1+s_{i 0}\right)^{2}+\left(1+p m_{i 0}\right)^{2}\right] / 3\right\}^{1 / 2}
$$

or using Equation (10):

$$
\begin{aligned}
& \text { ISUMP } \\
& =100\left\{\left[\left(1+m s_{i 0}\right)^{2}+\left(1+s_{i 0}\right)^{2}+(1+\pi)^{2} /\left(1+s_{i 0}\right)^{2}\right] / 3\right\}^{1 / 2}
\end{aligned}
$$

\subsection{Market Strategy Implementation Performance}

In many cases, a firm may equally value sales, market share, and profit achievement. Alternatively, when introducing a new product line, a firm may select a strategy of fast market penetration. In this case, sales and market shares may be assigned a higher weight than immediate profits. In other instances, the firm may select a market skimming strategy. In this case, profits may be given more importance relative to market share. Other strategies may be pursued. In such cases, selling units that are given the responsibility to implement market strategies, and it seems natural to assess the units' market performance at implementing them. This issue can be easily handled by management assigning different weights reflecting the relative importance of the three outcomes. Let:

$$
\begin{aligned}
& \alpha=\text { weight assigned to market share increases } \\
& \beta=\text { weight assigned to sales volume increases } \\
& \gamma=\text { weight assigned to profit margin increases }
\end{aligned}
$$
with

$$
\alpha+\beta+\gamma=1
$$

In this case, a straight application of these weights to the corresponding dimensions lead to a new expression of the Index of Selling Unit Market Performance (ISUMP): 


$$
\begin{aligned}
& \text { ISUMP } \\
& =100\left\{\frac{\alpha^{2}\left(1+m s_{i 0}\right)^{2}+\beta^{2}\left(1+s_{i 0}\right)^{2}+\gamma^{2}\left(1+p m_{i 0}\right)^{2}}{\left(\alpha^{2}+\beta^{2}+\gamma^{2}\right)}\right\}^{1 / 2}
\end{aligned}
$$

In addition, when management wishes to assess selling units' performance at implementing different market strategies for different product lines, the analysis may be carried out for the various product lines separately. Then, management may assign different weights to the product lines reflecting their relative strategic importance. A weighted market performance index is computed for every unit, and compared to the corresponding higher level selling entity's ISUMP.

\section{Application}

This procedure has been implemented in a large NorthAmerican insurance company which sells directly to customers with no intermediary involved. Like many North American insurance companies, this firm lacked adequate means to properly assess the market performance of the various selling units (sales agents and sales managers) at developing their territories over time. Thus, the general sales manager was highly concerned about the current market performance evaluation procedure where sales managers were essentially relying on one single criterion, i.e., the sales volume achieved in each territory. As a result, several salespersons grew dissatisfied with this criterion: they argued that even though their sales grew slowly (or even decreased) their territory market share was increasing. Market share data were collected from internal services and communicated to the sales personnel each month.

In this case, the application involved all the branch offices covering the North American market. The company used 713 insurance agents under the supervision of sales managers in 28 sales territories. Because of space constraints, only the results of the 28 sales offices are reported here. In other words, the branch office has been selected as the selling unit. For that purpose, the required data are the summated results across territories belonging to a selling unit. Those were calculated by cumulating the results of the insurance agents they supervise.

\subsection{Cross-Sectional Market Performance Analysis}

Selecting an adequate time period length to assess performance variations is an important decision. Too short a period of time (e.g., monthly data) could lead to wide market performance variations and may hide the true longer term performance of some selling units. Alterna- tively, too long a period of time (e.g., more than one year) may not be flexible enough, especially if management bases some financial rewards on short-term performance. This is why it may be worthwhile to carry the analysis with various time period lengths, whenever possible. In this application, quarterly performance results were not judged by management to be stable enough. Consequently, a one-year time period length $(\mathrm{t}=$ one year) was deemed most appropriate.

In addition, management selected market performances achieved during the previous year as benchmarks for comparing current market performances. During that year, no new product had been launched, marketing investments had been normal and the market had remained pretty stable. For illustration purpose, for a sample of sales territories at both ends of the performance spectrum (ST1-ST3 and ST26-ST28), the first eight rows of Table 2 give the sales levels, industry sales (estimated by the internal services of the company), the territory market shares, and the gross profit margins during both Year 1 $\left(\mathrm{Y}_{1}\right)$ and $\mathrm{Year} 2\left(\mathrm{Y}_{2}\right)$, with $\mathrm{Y}_{0}$ as the benchmark situation.

The percentage variations (in decimal form) in sales $(s)$, industry sales $(i s)$, market shares $(m s)$, gross profits $(\pi)$ and gross profit margins $(\mathrm{pm})$ in Year 2 over Year 1 have been used for computing the Index of Selling Unit Market Performance (ISUMP), using Equation (11) or (12). In this application, gross profit margins were estimated as:

$$
\begin{aligned}
\text { Gross profit margins } \\
=\text { revenues }-(\text { sales cost }+ \text { general administration cost } \\
\quad+\text { costs of customer claims })
\end{aligned}
$$

The interpretation is straightforward: the ISUMP index relates market performance in every sales territory, relative to the benchmark year, taking into account the evolution of industry sales and consequently, the impacts of competition and other environmental factors in the territory.

Considering first the Year 2 results (excluding profits), as can be seen in Figure 2, among the four highest performing territories (ST25 to ST28), three are located in Zone 1. Overall, nine sales territories (or 32 percent) were high sales performers, located in Zone 1: the firm's position is aggressively strengthened in a declining opportunity market. In ten sales territories, i.e., 36 percent, market shares and sales volumes could increase while demand had been slightly increasing. These territories are located in Zone 2 and their managers have been able to take advantage of the industry sales growth in their territories. They include the second best performing territories (ST27) in which sales significantly increased in an almost stagnant market (borderline of Zone 2). In addition, six sales territories (21 percent) fell into Zone 4. Their managers may not have properly 
Table 2. Sales and territory market share variations over the benchmark period for selected sales territories.

\begin{tabular}{|c|c|c|c|c|c|c|c|}
\hline Sales Data & ST28 & ST27 & ST26 & $\ldots$ & ST3 & ST2 & ST1 \\
\hline$S_{0}$ & 38,375 & 22,251 & 27,438 & & 30,104 & 26,857 & 32,562 \\
\hline$I S_{0}$ & 170,860 & 119,913 & 194,451 & & 168,074 & 148,469 & 149,122 \\
\hline$M S_{0}$ & 0.2246 & 0.1856 & 0.1411 & & 0.1791 & 0.1809 & 0.2184 \\
\hline$P_{0}$ & $3,640,118$ & $1,307,837$ & $3,058,069$ & & $2,772,587$ & $1,981,117$ & $3,130,635$ \\
\hline$S_{1}$ & 39,730 & 23,106 & 28,092 & & 30,021 & 26,870 & 32,105 \\
\hline$I S_{1}$ & 168,894 & 120,262 & 194,174 & & 168,405 & 152,908 & 149,719 \\
\hline$M S_{1}$ & 0.2352 & 0.1921 & 0.1447 & & 0.1783 & 0.1757 & 0.2144 \\
\hline$P_{1}$ & $6,144,282$ & $1,612,006$ & $3,341,885$ & & $2,800,849$ & $2,786,131$ & $3,094,727$ \\
\hline \multicolumn{8}{|c|}{ Proportion Increases or Decreases } \\
\hline$s$ & 0.0353 & 0.0384 & 0.0238 & & -0.0028 & 0.0005 & -0.014 \\
\hline is & -0.0115 & 0.0029 & -0.0014 & & 0.0020 & 0.0299 & 0.004 \\
\hline$m s$ & 0.0474 & 0.0354 & 0.0253 & & -0.0047 & -0.0286 & -0.018 \\
\hline$p$ & 0.6879 & 0.2326 & 0.0928 & & 0.0102 & 0.4063 & -0.0115 \\
\hline$p m$ & 0.6303 & 0.1870 & 0.0674 & & 0.0130 & 0.4056 & 0.0025 \\
\hline \multicolumn{8}{|c|}{ ISUMP Based on Sales and Market Share Variations Only } \\
\hline ISUMP & 104.14 & 103.69 & 102.46 & & 99.63 & 98.61 & 98.4 \\
\hline Adjusted ${ }^{*}$ & 103.08 & 102.64 & 101.42 & & 98.61 & 97.6 & 97.4 \\
\hline Zone & Zone 1 & Zone 2 & Zone 1 & & Zone 6 & Zone 4 & Zone 6 \\
\hline \multicolumn{8}{|c|}{ ISUMP Based on Sales, Profit, and Market Share Variations } \\
\hline ISUMP & 126.85 & 108.92 & 103.90 & & 100.19 & 114.31 & 99.02 \\
\hline Adjusted $^{* *}$ & 106.14 & 91.15 & 86.94 & & 83.84 & 95.66 & 82.86 \\
\hline Zone & Zone 1a & Zone $2 \mathrm{a}$ & Zone 1a & & Zone $6 \mathrm{a}$ & Zone $4 \mathrm{a}$ & Zone $6 \mathrm{~b}$ \\
\hline
\end{tabular}

exploited the growth opportunities of their markets: their sales volumes increased in an expanding market, but not sufficiently to maintain the firm's market position at its original level. Finally, two sales territories (7 percent), performed pretty poorly: their management failed to exploit the market growth opportunities and weakened the firm's position in an expanding market (Zone 6). Only in one sales territory (4 percent) management could strengthen the firm's market position in a decreasing market demand, but not enough to keep the same sales rate (Zone 3). No sales territory has been observed in Zone 5.

The graphic illustration of Figure 2 allows a better diagnostic of the relative market performances in the different sales territories. Using these results, the top management learned that territories operated in different zones and that it was desirable to adopt different strategies for the territories in the various zones. For instance, it was decided to better reward the efforts of the best performing agents in Zone 1, who aggressively strengthened the firm's position in a declining market.
Adding the profit dimension to this analysis (bottom of Table 2) provides a somewhat different picture. In the insurance industry, the profitability of a company is characterized by a rigorous risk selection. Consequently, one observes substantial variations of profitability from one year to another depending on the rigor of the risk selection decisions. Sometimes, insurance agents subscribe bad risks in order to increase their sales. For this reason, great variability may exist between the indices depending on whether profits are taken into account or not.

Of the sales territories considered in this analysis, 22 (79 percent) fell into an a zone (profit margin increase). Only six (21 percent), fell into a $b$ zone and experienced a profit margin decrease. Consequently, because of these overall good results, the whole company experienced a high ISUMP index of 119.51. The highest performing sales territories show successively ISUMPs of 205.95, $16478,147.84,147.80$, and 142.18. The three lowest performing territories show ISUMPs of $87.38,98.26$, and 99.02. This shows that including the profit dimension 
into the analysis sheds some new light on the various territories' market performances. For example, ST5 with a below average sales performance (adjusted ISUMP $=$ 98.81), had a superior performance when profits were also considered (adjusted ISUMP $=123.71$ ). From a managerial point of view, sales territories that depart sharply from an ISUMP value of 100 should be considered for further diagnosis and possible corrective actions.

\subsection{Compararison with the Other Evaluation Methods}

One of the most frequently used bases for evaluating a unit's sales performance is sales increase/decrease over the last (similar) period. In the reported case study, variations of selling unit's sales as a measure of market performance does not fully account for the different territory situations (industry sales variations or market share evolution). As can be seen in Figure 1, a given level of sales decrease (for instance $\mathrm{s}=0.90$ ) can yield quite different market performance assessments, depending on whether the performance vector ends up in Zone 1, 2, or 4 .

Table 3 provides a comparison of the sales territory rankings based on their ISUMP scores (including profits) and based on sales variations exclusively. The Spearman coefficient of correlation is a low 0.100 . In addition, in the present case, several sales territories experienced a low market performance with the ISUMP index excluding profit and a good market performance with the index including profit.

\subsection{Strategic Market Performance Analysis}

This analysis has been extended to the cases where the firm would pursue either market penetration (MPS) or market skimming strategies (MSS) (versus an undifferentiated strategy giving equal importance to all three objectives). In such cases, top management could assign different weights to the three objectives (sales volume, market share, and profits). In these occurrences, the firm's management should clearly communicate those weights to all the concerned managers, and inform them of the strategic market priorities. As an example, management could assign the following weights:

$\begin{array}{lcc}\text { Weights for: } & \text { MSS } & \text { MPS } \\ \text { Market share increases } & \alpha=0.1 & \alpha=0.6 \\ \text { Sales volume increases } & \beta=0.3 & \beta=0.3 \\ \text { Profit increases } & \gamma=0.6 & \gamma=0.1 \\ \text { Total } & 1.0 & 1\end{array}$

The results obtained after application of Equation (14) are shown in Table 4. This firm would achieve a better overall market performance by following a market skimming strategy (ISUMP $=145.46$ (Year 1) and 140.64 (Year 2)), and a lower market performance by following a market penetration strategy (ISUMP $=102.82$ (Year 1) and 102.24 (Year 2)) or an undifferentiated strategy $($ ISUMP $=122.15($ Year 1) and 119.50 (Year 2)). ST28's market performance assessment would follow a very similar pattern. As a result, the adjusted ISUMP for ST28 remains very stable, irrespective of the strategy being followed (respectively 109.63, 107.93, and 108.26 for Year 1; 108.15, 103.77, and 106.45 for Year 2). Consequently, weighting the different elements included

Table 3. Comparison of managers' market performance under sales variations versus sales, profits, and market share variations.

\begin{tabular}{|c|c|c|c|c|c|}
\hline \multirow{2}{*}{$\begin{array}{l}\text { Sales } \\
\text { territories }\end{array}$} & \multicolumn{3}{|c|}{$\begin{array}{l}\text { Sales, Profits, and Market } \\
\text { Share Assessment Basis }\end{array}$} & \multicolumn{2}{|c|}{$\begin{array}{c}\text { Sales Assessment } \\
\text { Basis }\end{array}$} \\
\hline & Index & Zone & Ranking* & Index & Ranking* \\
\hline ST4 & 582.45 & Zone $4 \mathrm{a}$ & 1 & 0.0010 & 23 \\
\hline ST18 & 205.95 & Zone $2 \mathrm{a}$ & 2 & 0.0176 & 9 \\
\hline ST17 & 164.78 & Zone $2 \mathrm{a}$ & 3 & 0.0125 & 13 \\
\hline ST5 & 147.84 & Zone $3 \mathrm{a}$ & 4 & -0.0035 & 26 \\
\hline ST14 & 147.80 & Zone 1a & 5 & 0.0091 & 16 \\
\hline ST15 & 142.18 & Zone $2 \mathrm{a}$ & 6 & 0.0123 & 14 \\
\hline ST16 & 139.81 & Zone 1a & 7 & 0.0111 & 15 \\
\hline ST24 & 133.99 & Zone $2 \mathrm{a}$ & 8 & 0.0244 & 3 \\
\hline ST8 & 133.61 & Zone $4 \mathrm{a}$ & 9 & 0.0050 & 19 \\
\hline ST22 & 131.08 & Zone 1a & 10 & 0.0153 & 12 \\
\hline ST28 & 126.85 & Zone 1a & 11 & 0.0353 & 2 \\
\hline ST19 & 122.66 & Zone $2 \mathrm{a}$ & 12 & 0.0230 & 5 \\
\hline ST2 & 114.31 & Zone $4 \mathrm{a}$ & 13 & 0.0005 & 24 \\
\hline ST27 & 108.92 & Zone $2 \mathrm{a}$ & 14 & 0.0384 & 1 \\
\hline ST21 & 108.48 & Zone $2 b$ & 15 & 0.0161 & 10 \\
\hline ST7 & 107.08 & Zone $4 \mathrm{a}$ & 16 & 0.0051 & 18 \\
\hline ST13 & 105.97 & Zone $4 \mathrm{a}$ & 17 & 0.0198 & 7 \\
\hline ST12 & 105.78 & Zone $1 \mathrm{~b}$ & 18 & 0.0064 & 17 \\
\hline ST25 & 105.29 & Zone 1a & 19 & 0.0188 & 8 \\
\hline ST23 & 104.01 & Zone $2 \mathrm{a}$ & 20 & 0.0226 & 6 \\
\hline ST26 & 103.90 & Zone 1a & 21 & 0.0238 & 4 \\
\hline ST10 & 101.63 & Zone $2 \mathrm{a}$ & 22 & 0.0031 & 21 \\
\hline ST6 & 101.00 & Zone $4 \mathrm{a}$ & 23 & 0.0026 & 22 \\
\hline ST3 & 100.19 & Zone $6 \mathrm{a}$ & 24 & -0.0028 & 25 \\
\hline ST1 & 99.02 & Zone $6 \mathrm{~b}$ & 25 & -0.0140 & 27 \\
\hline ST9 & 98.26 & Zone $2 \mathrm{a}$ & 26 & 0.0040 & 20 \\
\hline ST20 & 87.38 & Zone 1a & 27 & 0.0154 & 11 \\
\hline Total Office & 119.51 & Zone $2 \mathrm{a}$ & & & \\
\hline
\end{tabular}

*Spearman's Rank Correlation $=0.100$. 
Table 4. Impact of various market strategies upon ISUMPS (yearly data).

\begin{tabular}{|c|c|c|}
\hline Sales Data & Year 1 & Year 2 \\
\hline \multicolumn{3}{|c|}{ SALES TERRITORY ST28 } \\
\hline$s$ & 0.0379 & 0.0353 \\
\hline$m s$ & 0.1058 & 0.0473 \\
\hline$p$ & 0.7817 & 0.6879 \\
\hline$p m$ & 0.7166 & 0.6303 \\
\hline \multicolumn{3}{|c|}{$\begin{array}{l}\text { ISUMP Based on a Market Skimming Strategy } \\
\qquad(\mathrm{a}=0.1, \mathrm{~b}=0.3, \mathrm{~g}=0.6)\end{array}$} \\
\hline ISUMP & 159.48 & 152.11 \\
\hline Adjusted & 109.63 & 108.15 \\
\hline \multicolumn{3}{|c|}{$\begin{array}{l}\text { ISUMP Based on a Market Penetration Strategy } \\
\qquad(\mathrm{a}=0.6, \mathrm{~b}=0.3, \mathrm{~g}=0.1)\end{array}$} \\
\hline ISUMP & 110.98 & 106.10 \\
\hline Adjusted & 107.93 & 103.77 \\
\hline \multicolumn{3}{|c|}{$\begin{array}{c}\text { ISUMP Based on Equal Weight for Sales, Profits, and Market Share } \\
\text { Variations }(\mathrm{a}=0.33, \mathrm{~b}=0.33, \mathrm{~g}=0.33)\end{array}$} \\
\hline ISUMP & 132.24 & 126.84 \\
\hline Adjusted & 108.26 & 106.14 \\
\hline \multicolumn{3}{|c|}{ TOTAL OFFICE } \\
\hline$s$ & 0.0171 & 0.0117 \\
\hline$m s$ & 0.0126 & 0.0087 \\
\hline$p$ & 0.5812 & 0.5153 \\
\hline$p m$ & 0.5546 & 0.4977 \\
\hline \multicolumn{3}{|c|}{$\begin{array}{l}\text { ISUMP Based on a Market Skimming Strategy } \\
\qquad(\mathrm{a}=0.1, \mathrm{~b}=0.3, \mathrm{~g}=0.6)\end{array}$} \\
\hline ISUMP & 145.46 & 140.64 \\
\hline \multicolumn{3}{|c|}{$\begin{array}{l}\text { ISUMP Based on a Market Penetration Strategy } \\
\qquad(\mathrm{a}=0.6, \mathrm{~b}=0.3, \mathrm{~g}=0.1)\end{array}$} \\
\hline ISUMP & 102.82 & 102.24 \\
\hline \multicolumn{3}{|c|}{$\begin{array}{l}\text { ISUMP Based on Equal Weight for Sales, Profits, and Market Share } \\
\text { Variations }(\mathrm{a}=0.33, \mathrm{~b}=0.33, \mathrm{~g}=0.33)\end{array}$} \\
\hline ISUMP & 122.15 & 119.50 \\
\hline
\end{tabular}

in the ISUMP index so as to reflect the selected market strategy makes it possible to assess how effective every selling unit has been at implementing this strategy.

Following implementation, the company's top managers in charge of business development in North America were impressed by the outcomes of this project. For the first time, they could make a sound analysis of the market performance in the different sales territories in terms of business development, which was not done before. For Year 2 annual sales territories' evaluation, top management used the results of this analysis for making a better allocation of its resources. They had at their disposal a sound basis for denying additional re- sources requested by some sales agents and assigning them to sales territories that could profitably take advantage of market opportunities. This method provided top management with a powerful tool that could help assess their own strategies and decisions and point to possible resource allocation improvements. In addition, managers could identify the zones with large untapped company potential for growth. Although the ISUMP indices are only indicators of market performance and do not provide a diagnosis, they could allow management to identify and question the sales managers in charge of every territory in order to find proper explanations for their market performance and plan actions to take advantage of every market opportunity.

\section{Advantages and Limits}

The proposed procedure has several advantages: First, it provides short-run and/or long-run sales market performance assessments that, as can be observed frequently in practice, are dimensions that many sales managers like to watch very closely. It reveals also which selling units could and/or should take advantage of market opportunities in order to reinforce the firm's market position, a typically long-term objective, generally implying customer relationship and loyalty building. Second, the proposed market performance measure is simple to compute and understand within a firm and its various selling units. It is based upon the three major ingredients of market performance, i.e., increases/decreases of 1) sales, 2) market share, and 3) profit, compared with some selected benchmark(s). These are elements over which selling units are generally recognized to exert direct influence, and that are easy to measure. As a result, this method can be implemented easily and at low cost as part of a CRM application or business intelligence tools. Third, the proposed market performance measurement process is fair. It provides selling units with evaluations that are commensurate with their actual market performance, by making the generally reasonable assumption that environmental conditions equally affect a firm and its competitors. Fourth, the procedure is dynamic, and can be applied over several consecutive periods of time, and/or with various time lengths. As a result, it can be a useful device for tracking selling unit market performance over time, for shorter or longer periods of time, depending on the objectives. Fifth, the ISUMP index can be applied to assess the market performance of various sales entities (from territories assigned to a sales teams or an individual salesperson, regional or district sales offices, to the whole sales organization) and for various product lines, providing a common basis for making useful comparisons among and across those entities. Finally, a firm could use the ISUMP indices for allocating financial rewards (such a quarterly bonus) for short-run 
market performance [65]. As can be seen from Equation (7), this amounts to providing a reward that is proportional to current sales $\left(S_{1}\right)$, but at a rate that is specific to each selling unit and that accounts for basic territory characteristics. Note that when selling teams are involved, one part of the bonus may be allocated according to the unit (e.g., regional office) market performance index, and one part according to individual market performance measures.

The proposed procedure has also a few limitations: First, this method is applicable in cases where several firms compete in the same market and when the considered firm does not hold too large a market position compared to its competitors. Second, random sales variations due to environmental uncertainties or unusual circumstances are accounted for only implicitly. For instance, an unexpected windfall sale would increase $S_{1}, s$, and consequently, provide too high a market performance evaluation for that period. Although the ISUMP indices are effective market performance diagnosis tools and point to more and/or less efficient selling units taking the territory conditions into account, they do not diagnose why such market performance levels have been reached. In other words, the ISUMP index can identify possible problems, but does not provide a diagnosis. Third, as a corollary, such market performance analyses should not prevent management from watching other more qualitative aspects of selling units' market performances. For instance many human aspects (such as, for instance, the characteristics of the salespersons or the sales teams in charge of the selling units, e.g., their experience or career stage) should be kept in mind when carrying such an analysis. This index may be considered along other indicators in order to obtain a complete picture of every selling unit market performance. Finally, the proposed method requires access to sufficiently reliable market share data for every selling unit. Note, however, that in many industries (like the pharmaceutical industry) firms have access to such syndicated data on a regular basis.

\section{Summary and Conclusion}

This paper has described a relatively simple procedure for assessing various selling units' market performance, not only in the short-run, but also accounting for a firm's market position improvement (or decay) a typical longterm firm's marketing concern and a more relevant selling unit's market performance measure. The assessment formula is simple to explain and easy to administer. It requires only three sets of data: selling units' sales volumes, market shares, and profits in the corresponding territories. In addition, the outcomes of a selected market strategy can be assessed easily. A firm can integrate this procedure into its CRM or other sales intelligence system easily and at low cost. This procedure has been illustrated with an actual case study. It has been shown to provide more adequate results (from a marketing point of view), and more equitable market performance assessments than more complex (or even simpler) comparable procedures.

There are several ways in which the proposed procedure could be extended or refined. For instance, it could be modified to account for various variables, such as random factors and uncertainties. It should be kept in mind, however, that these refinements would come at the cost of making the procedure more complex. Consequently, they should be included only if the new benefits are worth the additional complexity.

\section{REFERENCES}

[1] A. Baldauf, D. W. Cravens and N. F. Piercy, "Examining Business Strategy, Sales Management, and Salesperson Antecedents of Sales Organization Effectiveness," Journal of Personal Selling \& Sales Management, Vol. 21, No. 2, 2001, pp. 109-122.

[2] S. P. Brown and R. A. Peterson, "Antecedents and Consequences of Salesperson Job Satisfaction: Meta-Analysis and Assessment of Causal Effects," Journal of Marketing Research, Vol. 30, No. 1, 1993, pp. 63-77. doi: $10.2307 / 3172514$

[3] G. A. Churchill, N. M. Ford, S. W. Harley and O. C. Walker, "The Determinants of Salesperson Performance: A Meta-Analysis," Journal of Marketing Research, Vol. 22, No. 2, 1985, pp. 103-118. doi:10.2307/3151357

[4] M. J. Barone and T. E. DeCarlo, "Performance Trends and Salesperson Evaluations: The Moderating Roles of Evaluation Task, Managerial Risk Propensity, and Firm Strategic Orientation," Journal of Personal Selling \& Sales Management, Vol. 32, No. 2, 2012, pp. 207-224. doi:10.2753/PSS0885-3134320203

[5] H. C. Barksdale, D. N. Bellenger, J. S. Boles and T. G. Brashear, "The Impact of Realistic Job Previews and Perceptions of Training on Sales Force Performance and Continuance Commitment: A Longitudinal Test," Journal of Personal Selling \& Sales Management, Vol. 23, No. 2, 2003, pp. 125-138.

[6] F. Jaramillo, F. A. Carrillat and W. B. Locander, "A MetaAnalytic Comparison of Managerial Ratings and SelfEvaluations," Journal of Personal Selling \& Sales Management, Vol. 25, No. 4, 2006, pp. 315-328.

[7] S. McKay, J. F. Hair, M. W. Johnston and D. L. Sherrell, "An Exploratory Investigation of Reward and Corrective Responses to Salesperson Performance: An Attributional Approach," Journal of Personal Selling \& Sales Management, Vol. 11, No. 2, 1991, pp. 39-48.

[8] M. H. Morris, D. L. Davis, J. W. Allen, R. A. Avila and J. Chapman, "Assessing the Relationships among Performance Measures, Managerial Practices, and Satisfaction when Evaluating the Salesforce: A Replication and Extension," Journal of Personal Selling \& Sales Manage- 
Ment, Vol. 11, No. 3, 1991, pp. 25-35.

[9] L. B. Chonko, T. W. Low, J. A. Roberts and J. F. Tanner, "Sales Performance: Timing of Measurement and Type of Measurement Make a Difference," Journal of Personal Selling \& Sales Management, Vol. 20, No. 1, 2000, pp. 23-36.

[10] R. A. Avila, E. F. Fern and O. K. Mann, "Unravelling Criteria for Assessing the Performance of Salespeople: A Causal Analysis," Journal of Personal Selling \& Sales Management, Vol. 8, No. 2, 1988, pp. 45-54.

[11] S. B. MacKenzie, P. M. Podsakoff and M. Aherne, "Some Possible Antecedents and Consequences of In-Role and Extra-Role Salesperson Performance," Journal of Marketing, Vol. 62, No. 3, 1998, pp. 87-98. doi:10.2307/1251745

[12] L. S. Silver, S. Dwyer and B. Alford, "Learning and Performance Goal Orientation of Salespeople Revisited: The Role of Performance-Approach and Performance-Avoidance Orientations," Journal of Personal Selling \& Sales Management, Vol. 26, No. 1, 2006, pp. 27-38. doi:10.2753/PSS0885-3134260103

[13] D. Berry, "Sales Performance: Fact or Fiction?" Journal of Personal Selling \& Sales Management, Vol. 6, No. 3, 1986, pp. 71-79.

[14] J. S. Boles, N. Donthu and R. Lohtia, "Salesperson Evaluation Using Relative Performance Efficiency: The Application of Data Envelopment Analysis," Journal of Personal Selling \& Sales Management, Vol. 15, No. 3, 1995, pp. 31-49.

[15] W. L. Cron and M. Levy, "Sales Management Performance Evaluation: A Residual Income Perspective," Journal of Personal Selling \& Sales Management, Vol. 7, No. 3, 1987, pp. 57-66.

[16] D. J. Dalrymple and W. M. Strahle, "Career Path Charting: Framework for Sales Force Evaluation," Journal of Personal Selling \& Sales Management, Vol. 10, No. 3, 1990, pp. 59-68.

[17] A. J. Dubinsky, S. J. Skinner and T. E. Whittler, "Evaluating Sales Personnel: An Attribution Theory Perspective," Journal of Personal Selling \& Sales Management, Vol. 9, No. 2, 1989, pp. 9-21.

[18] M. R. Edwards, W. T. Cummings and J. L. Schlacter, "The Paris-Peoria Solution: Innovations in Appraising Regional and International Sales Personnel," Journal of Personal Selling \& Sales Management, Vol. 4, No. 4, 1984, pp. 26-38.

[19] J. W. Gentry, J. C. Mowen and L. Tasaki, "Salesperson Evaluation: A Systematic Structure for Reducing Judgmental Biases," Journal of Personal Selling \& Sales Management, Vol. 11, No. 2, 1991, pp. 27-38.

[20] D. Jobber, G. J. Hooley and D. Shipley, "Organizational Size and Salesforce Evaluation Practices," Journal of Personal Selling \& Sales Management, Vol. 13, No. 2, 1993, pp. 37-48.

[21] R. G. McFarland and B. Kidwell, "An Examination of Instrumental and Expressive Traits on Performance: The Mediating Role of Learning, Prove, and Avoid Goal Orientation," Journal of Personal Selling \& Sales Manage- ment, Vol. 26, No. 2, 2006, pp. 143-159. doi:10.2753/PSS0885-3134260203

[22] J. P. Muczyk and M. Gable, "Managing Sales Performance through a Comprehensive Performance Appraisal System," Journal of Personal Selling \& Sales Management, Vol. 7, No. 2, 1987, pp. 41-52.

[23] O. C. Walker, G. A. Churchill and N. M. Ford, "Motivation and Performance in Industrial Selling: Present Knowledge and Needed Research," Journal of Marketing Research, Vol. 14, No. 2, 1977, pp. 156-158. doi: $10.2307 / 3150465$

[24] T. E. DeCarlo, R. K. Teas and J. C. McElroy, "Salesperson Performance Attribution Processes and the Formation of Expectancy Estimates," Journal of Personal Selling \& Sales Management, Vol. 17, No. 3, 1997, pp. 1-17.

[25] B. C. Krishnan, R. G. Netemeyer and J. S. Boles, "SelfEfficacy, Competitiveness, and Effort as Antecedents of Salesperson Performance," Journal of Personal Selling \& Sales Management, Vol. 22, No. 4, 2002, pp. 285-295.

[26] R. E. Plank and J. N. Greene, "Personal Construct Psychology and Personal Selling Performance," European Journal of Marketing, Vol. 30, No. 7, 1996, pp. 25-48. doi:10.1108/03090569610123807

[27] R. E. Plank and D. A. Reid, "The Mediating Role of Sales Behavior: An Alternative Perspective of Sales Performance and Effectiveness," Journal of Personal Selling \& Sales Management, Vol. 14, No. 3, 1994, pp. 43-56.

[28] B. A. Weitz, "Effectiveness in Sales Interactions: A Contingency Framework," Journal of Marketing, Vol. 45, No. 1, 1981, pp. 85-104. doi:10.2307/1251723

[29] B. A. Weitz, H. Sujan and M. Sujan, "Knowledge, Motivation, and Adaptive Behavior: A Framework for Improving Selling Effectiveness," Journal of Marketing, Vol. 50, No. 4, 1986, pp. 174-191. doi:10.2307/1251294

[30] G. J. Avlonitis and N. G. Panagopoulos, "Role Stress, Attitudes, and Job Outcomes in Business-to-Business Selling: Does the Type of Selling Situation Matter?" Journal of Personal Selling \& Sales Management, Vol. 26, No. 1, 2006, pp. 67-77. doi:10.2753/PSS0885-3134260106

[31] L. B. Chonko, R. D. Howell and D. N. Bellenger, "Congruence in Sales Force Evaluations: Relation to Sales Force Perceptions of Conflict and Ambiguity," Journal of Personal Selling \& Sales Management, Vol. 6, No. 2, 1986, pp. 35-48

[32] T. B. Flaherty, R. Dahlstrom and S. J. Skinner, "Organizational Values and Role Stress as Determinants of Customer-Oriented Selling Performance," Journal of Personal Selling \& Sales Management, Vol. 19, No. 2, 1999, pp. 1-18.

[33] D. N. Behrman and W. D. Perreault, "Measuring the Performance of Industrial Salespersons," Journal of Business Research, Vol. 10, No. 3, 1982, pp. 355-369. doi:10.1016/0148-2963(82)90039-X

[34] D. N. Behrman and W. D. Perreault, "A Role Stress Model of the Performance and Satisfaction of Industrial Salespersons," Journal of Marketing, Vol. 48, No. 4, 1984, pp. 9-21. doi:10.2307/1251506 
[35] G. K. Hunter and W. D. Perreault, "Sales Technology Orientation, Information Effectiveness, and Sales Performance," Journal of Personal Selling \& Sales Management, Vol. 26, No. 2, 2006, pp. 95-113. doi:10.2753/PSS0885-3134260201

[36] R. W. Giacobbe, D. W. Jackson, L. A. Crosby and C. M. Bridges, "A Contingency Approach to Adaptive Selling Behavior and Sales Performance: Selling Situations and Salesperson Characteristics," Journal of Personal Selling \& Sales Management, Vol. 26, No. 2, 2006, pp. 115-142. doi:10.2753/PSS0885-3134260202

[37] F. Jaramillo, J. P. Mulki and P. Solomon, "The Role of Ethical Climate on Salesperson's Role Stress, Job Attitudes, Turnover Intention, and Job Performance," Journal of Personal Selling \& Sales Management, Vol. 26, No. 3, 2006, pp. 271-282. doi:10.2753/PSS0885-3134260302

[38] W. E. Patton and R. H. King, "The Use of Human Judgment Models in Evaluating Sales Force Performance," Journal of Personal Selling \& Sales Management, Vol. 5, No. 2, 1985, pp. 1-14.

[39] W. H. Bommer, J. L. Johnson, G. A. Rich, P. M. Podsakoff and S. B. MacKennzie, "On the Interchangeability of Objective and Subjective Measures of Employee Performance: A Meta-Analysis," Personnel Psychology, Vol. 48, No. 3, 1995, pp. 587-605. doi:10.1111/j.1744-6570.1995.tb01772.x

[40] H. G. Heneman, "The Relationship between Supervisory Ratings and Result-Oriented Measures of Performance: A Meta-Analysis," Personnel Psychology, Vol. 39, No. 1, 1986, pp. 811-826.

[41] G. W. Marshall and J. C. Mowen, "An Experimental Investigation of the Outcome Bias in Salesperson Performance Evaluations," Journal of Personal Selling \& Sales Management, Vol. 13, No. 3, 1993, pp. 31-47.

[42] G. W. Marshall, J. C. Mowen and K. J. Fabes, "The Impact of Territory Difficulty and Self versus Other Ratings on Managerial Evaluations of Sales Personnel," Journal of Personal Selling \& Sales Management, Vol. 12, No. 4, 1992, pp. 35-47.

[43] J. C. Mowen, S. W. Brown and D. W. Jackson, "Cognitive Biases in Sales Management Evaluations," Journal of Personal Selling \& Sales Management, Vol. 1, No. 4, 1980, pp. 83-89.

[44] G. A. Rich, W. H. Bommer, S. B. MacKenzie, P. M. Podsakoff and J. L. Johnson, "Methods in Sales Research: Apples and Apples or Apples and Oranges? A MetaAnalysis of Objective and Subjective Measures of Salesperson Performance," Journal of Personal Selling \& Sales Management, Vol. 19, No. 4, 1999, pp. 41-52.

[45] F. Jaramillo, F. A. Carrillat and W. B. Locander, "Response to Comments: Starting to Solve the Method Puzzle in Salesperson Self-Report Evaluation," Journal of Personal Selling \& Sales Management, Vol. 24, No. 2, 2004, pp. 141-155.

[46] A. Sharma, G. A. Rich and M. Levy, "Comment: Starting to Solve the Method Puzzle in Salesperson Self-Report Evaluations," Journal of Personal Selling \& Sales Management, Vol. 24, No. 2, 2004, pp. 135-139.

[47] C. E. Pettijohn, L. S. Pettijohn and A. J. Taylor, "An Ex- ploratory Analysis of Salesperson Perceptions of the Criteria Used in Performance Appraisals, Job Satisfaction, and Organizational Commitment," Journal of Personal Selling \& Sales Management, Vol. 20, No. 2, 2000, pp. 77-80.

[48] D. W. Jackson, J. E. Keith and J. L. Schlacter, "Evaluation of Selling Performance: A Study of Current Practices," Journal of Personal Selling \& Sales Management, Vol. 3, No. 4, 1983, pp. 42-51.

[49] B. K. Pilling, N. Donthu and S. Henson, "Accounting for the Impact of Territory Characteristics on Sales Performance: Relative Efficiency as a Measure of Salesperson Performance," Journal of Personal Selling \& Sales Management, Vol. 19, No. 2, 1999, pp. 35-45.

[50] G. Challagalla and T. Shervani, "Dimensions and Types of Supervisory Controls: Effects on Salesperson Performance and Satisfaction," Journal of Marketing, Vol. 60, No. 1, 1996, pp. 89-105. doi:10.2307/1251890

[51] D. W. Cravens, T. N. Ingram, R. W. LaForge and C. E. Young, "Behavior-Based and Outcome-Based Salesforce Control Systems," Journal of Marketing, Vol. 57, No. 4, 1993, pp. 47-59. doi:10.2307/1252218

[52] R. L. Oliver and E. Anderson, "An Empirical Test of the Consequences of Behavior- and Outcome-Based Sales Control Systems," Journal of Marketing, Vol. 58, No. 4, 1994, pp. 53-67. doi:10.2307/1251916

[53] K. R. Bartkus, M. F. Peterson and D. N. Bellenger, "Type A Behavior, Experience, and Salesperson Performance," Journal of Personal Selling \& Sales Management, Vol. 9, No. 3, 1989, pp. 11-18.

[54] D. W. Cravens, R. W. LaForge, G. M. Pickett and C. E. Young, "Incorporating a Quality Improvement Perspective into Measures of Salesperson Performance," Journal of Personal Selling \& Sales Management, Vol. 13, No. 1, 1993, pp. 1-14.

[55] M. R. Hyman and J. S. Sager, "Marginally Performing Salespeople: A Definition," Journal of Personal Selling \& Sales Management, Vol. 19, No. 4, 1999, pp. 67-74.

[56] B. J. Jaworski, "Toward a Theory of Marketing Control: Environmental Context, Control Types, and Conse quences," Journal of Marketing, Vol. 52, No. 3, 1988, pp. 2339. doi: $10.2307 / 1251447$

[57] R. L. Oliver and E. Anderson, "Behavior- and OutcomeBased Sales Control Systems: Evidence and Consequences of Pure-Form and Hybrid Governance," Journal of Personal Selling \& Sales Management, Vol. 15, No. 4, 1995, pp. 1-16.

[58] W. G. Ouchi and M. Mcguire, "Organizational Control: Two Functions," Administrative Science Quarterly, Vol. 20, No. 4, 1975, pp. 559-569. doi:10.2307/2392023

[59] J. C. Mowen, K. J. Fabes and R. W. LaForge, "Effects of Effort, Territory Situation, and Rater on Salesperson Evaluation," Journal of Personal Selling \& Sales Management, Vol. 6, No. 2, 1986, pp. 1-8.

[60] J. U. Farley, "An Optimal Plan for Salesmen's Compensation," Journal of Marketing Research, Vol. 1, No. 1, 1964, pp. 39-44. doi:10.2307/3149920

[61] A. Sharma and D. Sarel, "The Impact of Customer Sa- 
tisfaction Based Incentive Systems on Salespeople's Customer Service Response: An Empirical Study," Journal of Personal Selling \& Sales Management, Vol. 15, No. 3, 1995, pp. 17-29.

[62] A. Cohen, "General Electric," Sales \& Marketing Management, Vol. 149, No. 4, 1997, p. 57.

[63] A. Charnes, W. W. Cooper and E. Rhodes, "Measuring the Efficiency of Decision-Making Units," European Journal of Operational Research, Vol. 2, No. 1, 1978, pp. 429-
444. doi:10.1016/0377-2217(78)90138-8

[64] L. M. Parsons, "Productivity versus Relative Efficiency in Marketing: Past and Future?" In: G. Lilien, G. Laurent, and B. Pras, Ed., Research Traditions in Marketing, Kluwer, Amsterdam, 1992, pp. 169-196.

[65] J. McAdams, "Rewarding Sales and Marketing Performance," Management Review, Vol. 12, No. 2, 1987, pp. 33-38. 